\title{
Benign Prostatik Patolojilerde Regülatuvar T Hücrelerinin (Treg) Değerlendirilmesi: Pilot Çalışma
}

\author{
Evaluation of Regulatory T-Cells (Tregs) in Benign Prostatic Pathologies: A Pilot Study \\ Erhan ATES ${ }^{1}$, Akin Soner AMASYALI ${ }^{2}$, Erman ORYASIN ${ }^{3}$, Irfan YAVASOGLU ${ }^{4}$, Mustafa YILMAZ ${ }^{5}$, \\ Bulent BOZDOGAN ${ }^{6}$, Haluk EROL ${ }^{1}$
}

\begin{abstract}
${ }^{1}$ Aydin Adnan Menderes University School of Medicine, Department of Urology, Aydin, Turkey.
${ }^{2}$ Loma Linda University Department of Urology, Loma Linda, California, USA.

${ }^{3}$ Aydin Adnan Menderes University School of Medicine, Recombinant DNA and Recombinant Protein Research Center, Aydin, Turkey.

${ }^{4}$ Aydin Adnan Menderes University School of Medicine, Department of Internal Diseases, Division of Hematology, Aydin, Turkey.

${ }^{5}$ Aydin Adnan Menderes University School of Medicine, Department of Medical Biochemistry, Aydin, Turkey.

${ }^{6}$ Aydin Adnan Menderes University School of Medicine, Medical Microbiology, Aydin, Turkey
\end{abstract}

\section{Özet}

Amaç: Histopatolojik olarak benign prostat hiperplazisi (BPH) ve asemptomatik kronik prostatit(AKP) tanısı alan hastaların periferik kan ve prostat dokularındaki regülatuvar T (Treg) hücrelerinin sayı ve işlevini değerlendirmeyi amaçladık.

Gereç ve Yöntemler:Transüretral prostat rezeksiyonu yapılan 19 hastanın (BPH = 10, AKP = 9)kan ve histopatolojik verileri değerlendirildi. Flowsitometri ile periferik kan ve prostat dokusunda Treg hücre sayımı, revers transkripsiyon polimeraz zincir reaksiyonu (PCR) ile prostatic dokuda Forkhead box P3 (FOXP3) ekspresyonu ve ELISA ile kan örneklerinde IL-17 ölçümü yapıldı.

Bulgular: Flowsitometrik analizler, hem periferik kanda $(\mathrm{CD} 4+\mathrm{T}, \mathrm{p}=0.752 ; \mathrm{FOXP} 3, \mathrm{p}=1.000)$ hem de prostat dokusunda $(\mathrm{CD} 4+\mathrm{T}, \mathrm{p}=0.458$; FOXP3, $\mathrm{p}$ $=0.590$ ) ortalama CD4+ T hücre sayıs1 ve ortalama FOXP3 düzeylerinin BPH grubunda kronik prostatit grubuna gore daha yüksek olduğunu göstermiștir. Ancak bu fark istatistiksel olarak anlamlı değildi. Benzer şekilde, ortalama IL-17 seviyeleri de BPH grubunda yüksekti, ancak fark istatistiksel olarak anlamlı değildi ( $\mathrm{p}=0.870)$. PCR analizleri, dokudaki ortalama FOXP3 gen ekspresyonunun kronik prostat grubunda daha yüksek olduğunu, ancak yine gruplar arasında istatistiksel olarak anlamlı bir fark olmadığını gösterdi $(\mathrm{p}=0.116)$.

Sonuç: Periferik kandaki ve prostat dokusundaki Treg hücre sayısı ve fonksiyonu açısından BPH ile kronik prostatit arasında istatistiksel olarak anlamlı bir fark bulunamadığından, çalışmamız her iki patolojinin de otoimmün inflamatuvar hastalıklar olabileceği tezini desteklemektedir.

Anahtar Kelimeler: Otoimmünite, Enflamasyon, Benign Prostat Hiperplazisi, Kronik prostatit, FOXP3, Regülatuvar T hücreleri

\section{Abstract}

Objective:We aimed to evaluate the number and function of regulatory T (Treg) cells in peripheral blood and prostate tissues of patients with histopathologically diagnosed benign prostate hyperplasia (BPH) and asymptomatic chronic prostatitis.

Material and Methods:Blood and histopathological data of 19 patients $(\mathrm{BPH}=10, \mathrm{ACP}=9)$ that underwent transurethral prostate resection were evaluated. Treg cell count in peripheral blood and prostatic tissue with flowcytometry, Forkhead box P3(FOXP3) expression in prostatic tissue by reverse transcription polymerase chain reaction (PCR), and IL-17 measurement in blood samples with ELISA were performed.

Results: Flowcytometric analyses showed that mean CD4+T cell count and mean FOXP3 levels in both peripheral blood $(\mathrm{CD} 4+\mathrm{T}$, $\mathrm{p}=0.752$; FOXP3, $\mathrm{p}=$ $1.000)$ and prostate tissue $(\mathrm{CD} 4+\mathrm{T}, \mathrm{p}=0.458$; FOXP3, $\mathrm{p}=0.590)$ were higher in the BPH group compared to the chronic prostatitis group. However this difference was not statistically significant. Similarly, the mean blood IL-17 levels were also higher in BPH groups, but the difference was not statistically significant $(\mathrm{p}=0.870)$. The PCR analyses showed that mean FOXP3 gene expression in the tissue was higher in the chronic prostate group, but again there was no statistically significant difference between the groups $(\mathrm{p}=0.116)$.

Conclusion: Since no statistically significant difference was found between BPH and chronic prostatitis in terms of Treg cell number and function in peripheral blood and prostatic tissue, our study supports the thesis that both these pathologies could be autoimmune inflammatory diseases.

Keywords: Autoimmunity, Inflammation, Benign Prostate Hyperplasia, Chronic prostatitis, FOXP3, Regulatory T cells

Yazışma Adresi: Erhan ATEŞ, Aydın Adnan Menderes Üniversitesi Tıp Fakültesi Hastanesi Üroloji ABD, Aydın,Türkiye, Telefon: +90-506-5323143, Mail: drerhanates@yahoo.com

ORCID No (Sirasiyla): 0000-0002-9677-5673,0000-0003-3921-464X,0000-0003-1242-7434,0000-0003-1703-2175,0000-0002-3353-6595,0000-00032469-9728,0000-0003-4101-7565

Geliş tarihi: 3.11 .2020

Kabul tarihi: 27.11.2020

DOI: $10.17517 /$ ksutfd.820604 


\section{INTRODUCTION}

Prostatic inflammation is a common condition in prostate fluid and tissue samples, and it is seen in up to $70 \%$ (14 ) of needle biopsy samples and up to $100 \%$ of transurethral resection (TURP) tissue samples (4). Although the presence of prostatic inflammation is well defined, its etiology has not been clarified yet. Potential factors such as bacterial infections, intraprostatic urinary reflux, chemical inflammation, hormones, diet, metabolic syndrome, and autoimmunity have been suspected in the etiology, however multifactorial causes are more likely (5).

Prostate is an immunocompetent organ and its immune response is primarily $\mathrm{T}$ lymphocyte-mediated. This lymphocyte class constitutes more than $90 \%$ of prostate lymphocytes in both epithelial and stromal regions (6). In particular, regulatory T-cells (Treg) are mainly located in the fibromuscular stroma, while cytotoxic T-cell (cluster of differentiation- 8 [CD-8]) infiltrates are primarily distributed around the periglandular area (6).

Tregs are a subset of CD4+T cells that act as immunosuppressants by suppressing unwanted inflammatory responses to self-antigens and thus play a role in maintaining immune homeostasis. Tregs, which make up 5-10\% of CD4 + T cells, can be identified by the expression of the Forkhead box P3 (FOXP3) transcription factor and high surface expression of CD25. These cells function through a variety of mechanisms, including production of immunosuppressive cytokines such as transforming growth factor (TGF)-beta and interleukin (IL)-10, which inhibit cell-to-cell contact (7) and antigen-specific T cell responses (8). The most common patterns seen in autoimmune diseases are low number of normal functioning Tregs or normal number of low-functioning Tregs. Many issues regarding Tregs' control of autoreactivity are still being investigated (9).

Inflammatory infiltrates are seen in histological examinations of almost all surgical benign prostatic hyperplasia (BPH) specimens. Seventy percent of the infiltrate is T cells, $15 \%$ B cells, and $15 \%$ macrophages and mast cells. While $\mathrm{T}$ cell density increases with aging, this increase is reported as high as 28-fold in BPH patients (10). Nowadays, the hypothesis that $\mathrm{BPH}$ is an immune-mediated inflammatory disease with a localized autoimmune condition has become increasingly accepted (10-12). Jin et al. reported that Treg cell count was low in peripheral blood taken from BPH patientsand almost nonexistent in severely inflamed prostate tissue (13). Bai et al. determined that in patients with chronic prostatitis / chronic pelvic pain syndrome (CP / CPPS, category III prostatitis), FOXP3 mRNA and transforming growth factor beta 1 (TGF-1) levels were significantly lower, but serum tumor necrosis factor-alpha (TNF- $\alpha$ ) levels were higher than in control patients. They demonstrated that functional defects of Treg cells may play a role in the pathogenesis of benign inflammatory prostate pathology such as CP / CPPS and re- vealed autoimmune background of these diseases (14).

The results obtained from limited number of studies have led to the idea that Treg cell number and function should be similar in diseases such as BPH and chronic prostatitis, both of which are thought to involve autoimmune inflammation. In this study, we aimed to investigate and compare the autoimmune inflammatory infrastructure of these diseases by evaluating the number and function of Treg cells in peripheral blood and prostate tissues of patients with histopathologically diagnosed $\mathrm{BPH}$ and chronic prostatitis.

\section{MATERIAL and METHODS}

The study was planned according to the principles of the Helsinki Declaration. After the approval of the local ethics committee (Protocol No: 2017/1082), blood and histopathological data of 19 male patients that had lower urinary tract symptoms and underwent TUR-P with a clinical diagnosis of BPH between February 20, 2017 and February 20, 2018, were evaluated. Since prostatic inflammation was detected in $70 \%$ of needle biopsy samples and almost $100 \%$ of transurethral resection (TURP) tissue samples, we preferred to evaluate patients who underwent TUR-P in our study. The Treg cells were counted by flow cytometry. FOXP3 levels were determined by reverse transcription polymerase chain reaction method in the immunology laboratory. Flowcytometric method and polymerase chain reaction(PCR) analysis were preferred because of their accuracy and due to the fact that they are not dependent on the individual evaluations like immunohistochemical analysis. The IL-17, which is a Treg cell product, was also evaluated in the biochemistry laboratory with ELISA kit. Patients were divided into two groups as $\mathrm{BPH}$ and chronic prostatitis according to their histopathological results. Treg cell count and FOXP3 gene expression results of both groups were compared. Patients with cancer diagnosis and immunological disorders were excluded from the study.

\section{Flow Cytometric Evaluation}

Tissue samples were prepared for antibody treatment by processing with Medicon tissue disruptor. They were placed in the Medicon containing $1.5 \mathrm{cc}$ isotonic (flowsheath) buffer. Suspension was obtained with tissue lysis device. Fifty microliters of patient blood / tissue sample was placed in the sampling container. Two separate sample containers were used for blood and tissue samples. Five microliters of fixative reagent was added into each tube and samples were vortexed immediately. The samples were incubated at room temperature for 15 minutes and vortexed again after incubation. Three hundred microliters of permeabilizing reagent was added into each tube and $10 \mu \mathrm{L}$ fluoroconjugated antibodies against intracellular epitopes and surface molecules (CD45 Kro, CD4 - FITC, CD25 - PC7, FoxP3-Alexa Fluor647) were added into each tube. Samples were vortexed and incubated at room temperature for 20 minutes. Three milliliters of the sample was centrifuged at $500 \mathrm{~g}$ for 5 minutes and subjected 
to another wash to allow concentration of cells and ultimately increase the signal for rapid analysis in flowcytometry. After centrifugation, the supernatant was discarded and the pellet was resuspended in $0.5 \mathrm{ml} 1 / 10$ diluted final reagent (PerFix-nc). The samples were then analyzed in Beckman Coulter Navius 3 L10C flowcytometry device.

\section{FOXP3 Quantitative Reverse Transcriptase- Polymerase Chain Reaction (PCR)}

RNA extraction: Tissue samples were obtained from patients with BPH $(n=10)$ and chronic prostatitis $(n=9)$. RNA was extracted using the Gene Jet RNA extraction kit (ThermoFisherScientificInc.). Total RNA was measured by spectrophotometric analysis (ThermoNanoDrop ${ }^{\mathrm{Im}} 2000$ Spectrophotometer).

Reverse Transcription: cDNA synthesis was performed according to the manufacturer's instructions with random hexamer primers and reverse transcriptase enzyme provided in the First Strand cDNA Synthesis Kit (ABMGood, USA). The reverse transcription reaction incubation conditions were 5 minutes at $25^{\circ} \mathrm{C}$, followed by 1 hour at $42^{\circ} \mathrm{C}$ and 5 minutes at $70^{\circ} \mathrm{C}$.

Quantitative real-time polymerase chain reaction (qPCR): qPCR analysis to determine expression levels was performed with Step One Real Time PCR System (Applied Biosystems, Foster City, CA, USA). The qPCR primers and probes that were used were Foxp3 (Hs01085834 m1) and GAPDH (Hs02758991_g1) (endogenous control for normalization) from the pre-designed Taq Man gene expression assays. The cycling conditions were initial incubation at $95^{\circ} \mathrm{C}$ of 10 minutes, followed by 40 cycles of denaturation for 15 seconds at $95^{\circ} \mathrm{C}$ and extension for 1 minute at $60^{\circ} \mathrm{C}$.

\section{Detection of IL-17 by ELISA}

Venous blood samples were stored in tubes without anticoagulants. After 30-60 minutes incubation time, sampleswere centrifuged at $1000 \mathrm{~g}$ for 10 minutes. Serum samples were separated immediately, and stored at $-80^{\circ} \mathrm{C}$ for collective IL-17 ELISA tests. Serum IL-17 levels were analyzed by using commercial Fine Test kit (Catalog No; EH3267, Wuhan FineBiologicalTechnologyCo., Ltd., EastLikeHigh-Tech Development District, Wuhan, China). Test results were measured with an ELISA plate reader (ELX800, BioTek Instru- ments, Inc. Winooski, Vermont, USA) at $450 \mathrm{~nm}$. According to the manufacturer's data, the detection limit was $18.75 \mathrm{pg}$ $/ \mathrm{ml}$, the intra and inter-assay coefficient of variation $(\mathrm{CV})$ was $8 \%$, and the reading range was $31.25-2000 \mathrm{pg} / \mathrm{ml}$. The procedure was applied without any changes in line with the manufacturer's instructions.

\section{Statistical Analyses}

All data were transferred to the SPSS 25 statistical program. Kolmogorov-Smirnov test was used to evaluate whether the distribution of continuous variables was normal. Descriptive statistics were presented as mean $+/$ - SD. Comparisons between two groups of independent variables that were not normally distributed were done by using the Mann-Whitney $\mathrm{U}$ test, while normally distributed independent variables were analyzed by using the independent Student $\mathrm{T}$ test. A p value of $<0.05$ was considered statistically significant.

\section{RESULTS}

The mean age of 19 patients was $69.9 \pm 8.8$ years, and the mean PSA value was $3.71 \pm 2.3 \mathrm{ng} / \mathrm{mL}$. The pathological examination indicated that 10 patients had $\mathrm{BPH}$ and 9 patients had asymptomatic chronic prostatitis. The mean $\mathrm{CD} 4+\mathrm{T}$ cell count in peripheral blood was $0.8 \pm 0.41 \%$ in the BPH group (Figure 1), $0.76 \pm 0.37 \%(\mathrm{p}=0.752)$ in the chronic prostatitis group (Figure 2). Meanwhile, the mean CD4 + $\mathrm{T}$ cell count in the prostate tissue was $32.54 \pm 44.69 \%$ in the $\mathrm{BPH}$ group, and $14.76 \pm 29.15 \%(\mathrm{p}=0.458)$ in the chronic prostatitis group. The mean FOXP3 inflow cytometric measurements from blood samples were $1.03 \pm 0.92 \%$ in patients with BPH and $0.93 \pm 0.29 \%(\mathrm{p}=1.000)$ in patients with chronic prostatitis, while in tissue samples they were $3.5 \pm 3.44 \%$ in patients with $\mathrm{BPH}$ and $2.72 \pm 3.67 \%(\mathrm{p}=0.590)$ in patients with chronic prostatitis (Table 1). The PCR analyses showed that mean FOXP3 gene expression levels in the tissue was $0.00659 \pm 0.00612 \Delta \mathrm{Ct}$ in patients with $\mathrm{BPH}$ and 0.01554 $\pm 0.01456 \Delta \mathrm{Ct}$ in patients with chronic prostatitis. There was no significant difference between the two groups $(\mathrm{p}=0.116)$. Similarly, there was no significant difference between the two groups in terms of mean blood IL-17 levels with $254.70 \pm$ $282.32 \mathrm{pg} / \mathrm{ml}$ in BPH patients and $216.93 \pm 167.34 \mathrm{pg} / \mathrm{ml}$ in patients with chronic prostatitis $(\mathrm{p}=0.870)$. 

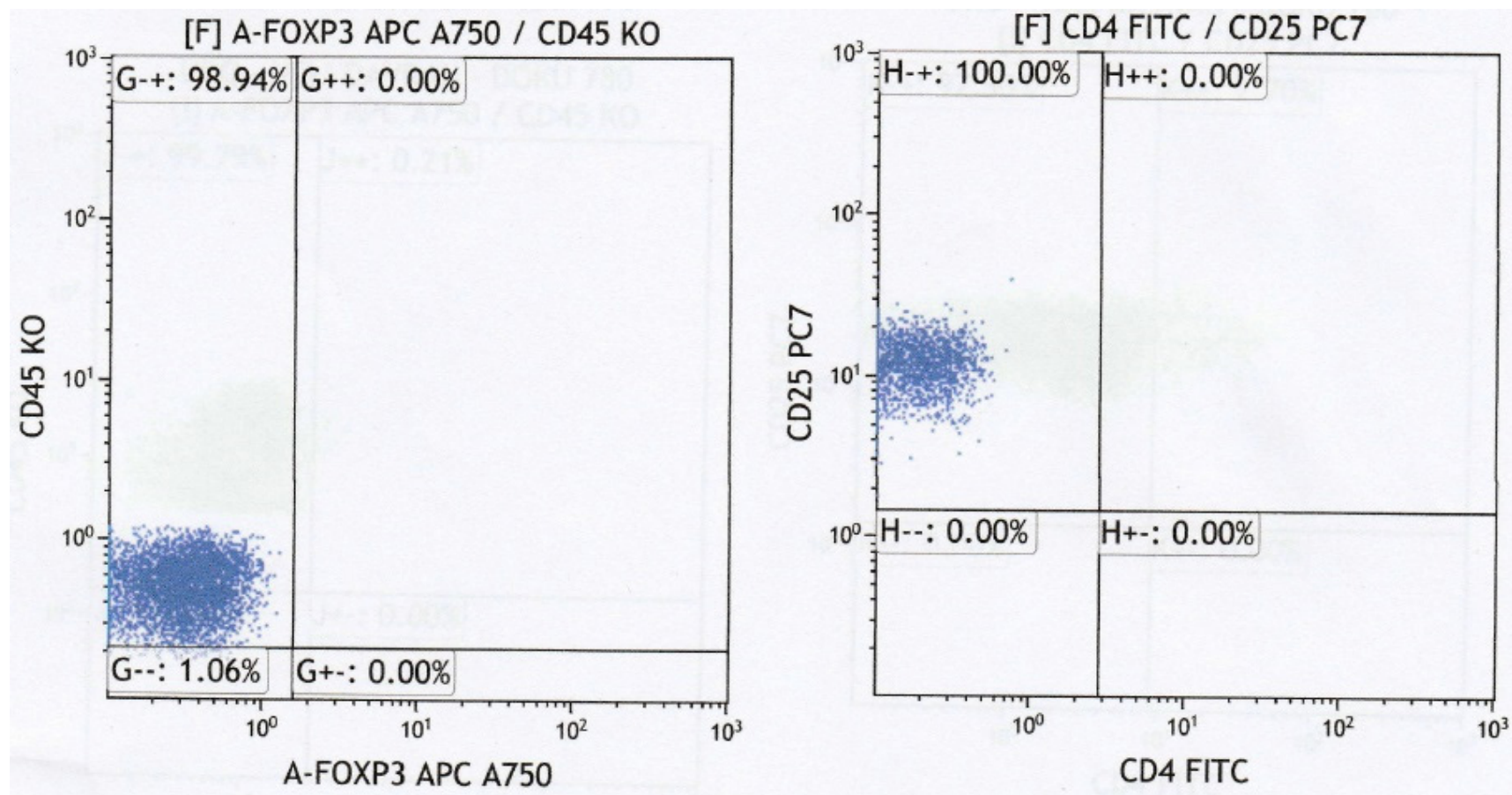

Figure 1. Flowcytometric evaluation in $\mathrm{BPH}$
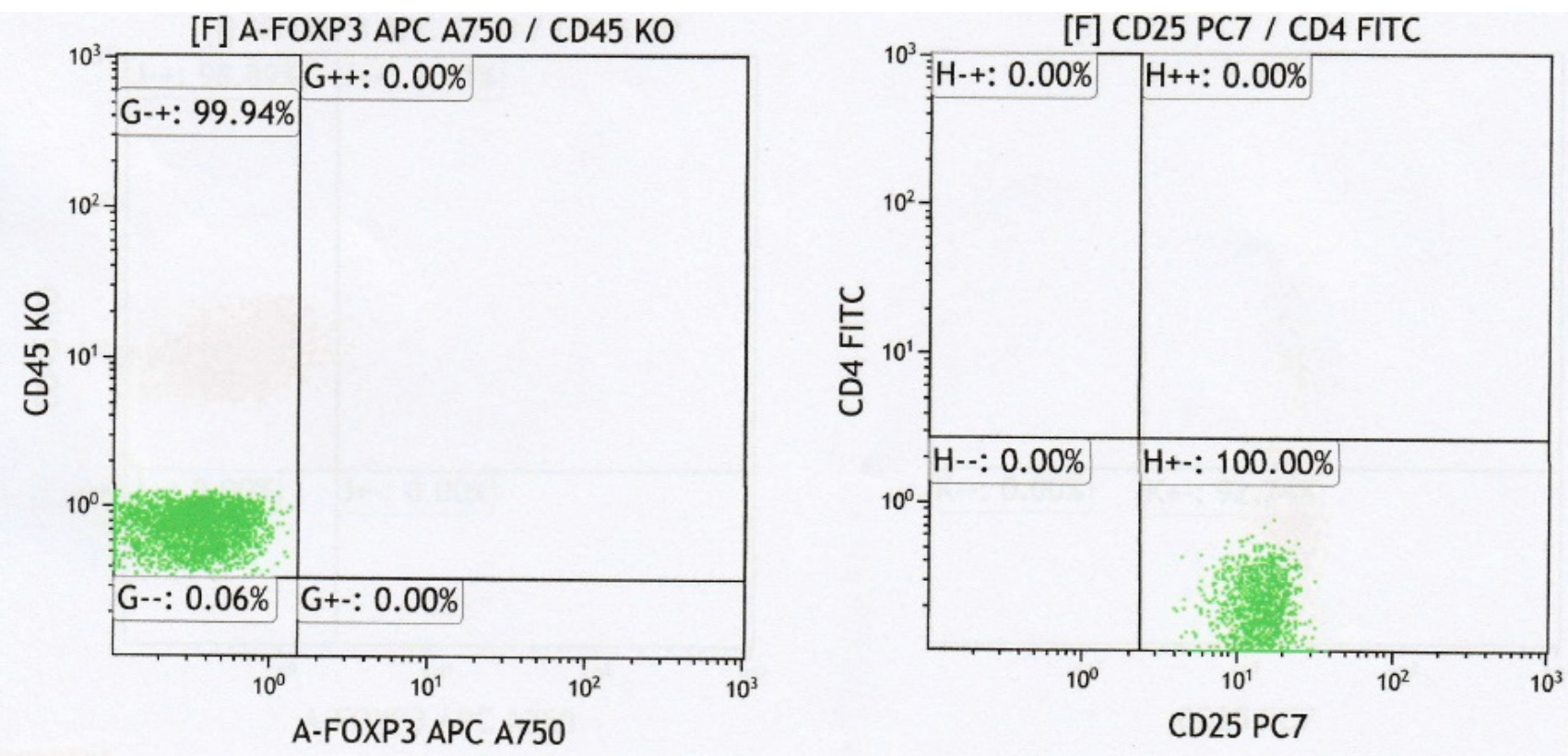

Figure 2. Flowcytometric evaluation in chronic prostatitis 
Table 1. Comparison of blood and tissue analysis of both groups

\begin{tabular}{|c|c|c|c|c|c|}
\hline & BPH (n:10) & & $\begin{array}{l}\text { Chronic Prostatitis } \\
\text { (n:9) }\end{array}$ & & \\
\hline & Mean & SD & Mean & SD & P Value \\
\hline Age year & 69,50 & 10,05 & 70,44 & 7,91 & 0,824 \\
\hline PSA, ng/mL & 3,64 & 2,47 & 3,79 & 2,30 & 0,887 \\
\hline \multicolumn{6}{|l|}{ Flow Cytometry Blood, (\%) } \\
\hline CD45 & 93,26 & 10,78 & 97,01 & 3,75 & 0,326 \\
\hline CD25 & 99,28 & 1,42 & 96,81 & 9,58 & 0,247 \\
\hline CD4 & 0,80 & 0,41 & 0,76 & 0,37 & 0,752 \\
\hline FOXP3 & 1,03 & ,92 & 0,91 & 0,29 & 1,000 \\
\hline \multicolumn{6}{|l|}{ Flow Cytometry Tissue, (\%) } \\
\hline CD45 & 97,26 & 8,67 & 98,38 & 2,91 & 0,155 \\
\hline CD25 & 98,05 & 4,38 & 100,00 &, 00 & 0,083 \\
\hline $\mathrm{CD} 4$ & 32,54 & 44,69 & 14,76 & 29,15 & 0,458 \\
\hline FOXP3 & 3,50 & 3,44 & 2,72 & 3,67 & 0,590 \\
\hline Tissue FoxP3 gene expression by PCR, $\Delta \mathrm{Ct}$ & 0,00659 & 0,00612 & 0,01554 & 0,01456 & 0,116 \\
\hline Blood IL-17 level, pg/ml & 254,7047 & 282,3251 & 216,9312 & 167,3445 & 0,870 \\
\hline
\end{tabular}

\section{DISCUSSION}

Considering that non-infectious causes are eight times more common in the origin of chronic inflammatory prostate diseases compared to bacterial prostatitis, autoimmune response is a more likely candidate for their etiology. Whether this immune reaction is initiated by foreign antigens, autoantigens or both is still under investigation (15). Evaluation of surgical samples obtained from BPH patients showed that almost all patients had inflammatory cell infiltration, mostly composed of $\mathrm{T}$ lymphocytes. In studies examining the inflammatory cell population in $\mathrm{BPH}$, it has been shown that $\mathrm{T}$ lymphocytes make up 70\%, B lymphocytes $15 \%$ and macrophages and mast cells the other $15 \%$ of the population, whereas granulocytes are mostly absent $(10,16)$. This high prevalence of immune cells supports the idea that the prostate is an immunocompetent organ.

Th17 strain, which was defined in the mid-2000s and is different from traditional Th1 and Th2 strains, revolutionized our understanding of the immunopathogenesis of chronic inflammation (17). Th17 cells produce the proinflammatory cytokine IL-17 and regulate host response to extracellular bacterial and fungal pathogens. They gain a high autoimmunogenic potential in cases of hyperresponsiveness and play a role in the pathogenesis of autoimmune diseases such as psoriasis, rheumatoid arthritis, and Crohn's disease by causing the development of chronic immune-mediated tissue destruction via proinflammatory cytokines such as IL-17A, IL-17F, IL-21 and IL-22 $(18,19)$. It has been shown that proinflammatory cytokines released from neighboring inflammatory cells induce cyclooxygenase-2 (COX-2) expression in epithelial cells, increasing the proliferation rate of cells in the prostate (20). Proinflammatory IL-17 produced by active $\mathrm{T}$ cells is increased in patients with $\mathrm{BPH}$ and is thought that this overexpression of IL-17 may play a role in elevated COX2 expression and increased prostate cell proliferation rate $(20,21)$. Penna et al. have demonstrated that human prostate stromal cells function as antigen-presenting cells and activate alloantigen-specific $\mathrm{CD} 4+\mathrm{T}$ cells to produce IFN-gamma and IL-17 (22). It is also thought that prostate stromal cells can induce and protect the autoimmune response (23). A number of prostate antigens, most of which are prostate's secretory products, also function as autoantigens. They have a high proteolytic activity, and when they reach periglandular tissue after epithelial damage, they can break down not only connective tissue cells, but also major matrix areas that allow autoantigenic molecules to gain wide access to the immune system of the prostate $(10,24,25)$. All this information supports the efficacy of autoimmune mechanism in chronic inflammatory pathologies of the prostate such as BPH and asymptomatic chronic prostatitis.

Treg cells are a subpopulation of $\mathrm{T}$ cells with immunosuppressive function. They shows their immunosuppressive effects by secreting suppressing cytokines such as IL-10 and TGF- $\beta$, by decreasing the local concentration of IL-2, triggering apoptosis, and stopping the cell cycle in cell-to-cell contact (8). Information on the role of Treg cells in the prostate is limited. Recently,Davidsson et al. have reported increased number of stromal CD4 + Tregs in patients with post-atrophic hyperplasia and prostate cancer (26). Jin et al. detected low Treg cell count in peripheral blood taken from $\mathrm{BPH}$ patients, but they found high Treg infiltration in prostate tissue with mild or moderate inflammation (13). They also found that Treg cells almost disappeared in severely inflamed prostate tissue, and suggested that this inconsistency was caused by the use of different patient samples (13). The transcription factor called FOXP3 controls the Treg cell system and is the most specific marker of these cells (27). Decrease in FOXP3 expression has been linked to human immune disorders (28). Bai et al. observed a lower FOXP3 mRNA expression level in CP / CPPS patients compared to the healthy control group and reported that functional defects of Treg cells may also play a role in the pathogenesis of CP / CPPS(14).

In our study, CD4+FOXP3+ cells and IL-17 levels in peripheral blood and prostate tissue were lower in the chronic prostatitis group than in the BPH group, but this difference was not 
significant. Moreover, although tissue FOXP3 gene expression was higher in the chronic prostatitis group, no significant difference was found between the groups. We believe that the fact that there was no significant difference between asymptomatic chronic prostatitis (category type IV) and BPH in terms of Treg number and function supports the hypothesis that inflammation and autoimmunity are factors in the etiopathogenesis of BPH.

Although the small number of patients is a limitation, our pilot study with a limited budget was still able to provide valuable data. Larger studies can be planned to investigate the correlation between Treg cell count and function and histopathological and / or clinical symptom intensity.

As a conclusion, Evaluating Treg cell number and function is an effective method for revealing autoimmune inflammation. Studies suggest that BPH and chronic prostatitis are autoimmune inflammatory diseases. The fact that we did not find any significant difference between the two pathologies in terms of Treg cell number and function in peripheral blood and prostatic tissue supports these theses. Unveiling the irregular immune pathways in the pathogenesis of these diseases can help design new anti-immune inflammatory drugs. Large scale multi-center studies are needed to achieve these goals.

Acknowledgements: This study supported by the Scientific Research Projects Management Unit of Aydin Adnan Menderes Univesity TPF-17050

\section{Conflicts of interest}

The authors declare that they have no conflict of interest.

Research Contribution Rate Statement Summary: The authors declare that, they have contributed equally to the manuscript.

\section{REFERENCES}

1. Delongchamps NB, de la Roza G, Chandan V, Jones R, Sunheimer R, Threatte G, Jumbelic M,Haas GP. Evaluation of prostatitis in autopsied prostates--is chronic inflammation more associated with benign prostatic hyperplasia or cancer? J Urol 2008; 179:1736-40.

2. Potts JM: Prospective identification of National Institutes of Health category IV prostatitis in men with elevated prostate specif icantigen. J Urol 2000; 164:1550-3.

3. Nickel JC, Roehrborn CG, O'Leary MP, Bostwick DG, Somerville MC, Rittmaster RS. Examination of the relationship between symptoms of prostatitis and histologic inflammation: baseline data fromthe REDUCE chemoprevention trial. J Urol 2007;178:896-901.

4. Nickel JC, Downey J, Young I, Boag S. Asymptomatic inflammation and/o rinfection in benign prostatic hyperplasia. BJU Int 1999; 84:976-81.

5. De Marzo AM, Platz EA, Sutcliffe S, Xu J, Grönberg H, Drake CG, Nakai Y, Isaacs WB, Nelson WG. Inflammation in prostate carcinogenesis. Nat Rev Cancer 2007; 7: 256-69.

6. Bostwick DG, de la Roza G, Dundore P, Corica FA, Iczkowski KA. Intra epithelial and stromal lymphocytes in the normal human prostate. Prostate 2003; 55: 187-93.

7. Shevach EM. Mechanisms of foxp3+ T regulatory cell-mediated suppression. Immunity. 2009;30:636-45

8. Sakaguchi S.Naturally arising CD4+ regulatory $\mathrm{T}$ cells for immunologic self tolerans and negative control of immune responses. Ann Rev Immunol 2004;22:531-62.

9. Valenci A, Lipsky PE. CD4+CD25+FoxP3+ regulatory T cells in auto immune diseases.Nat Clin Pract Rheumatol. 2007
Nov;3(11):619-26.

10. Steiner GE, Stix U, Handisurya A. Cytokine expression pattern in benign prostatic hyperplasia infiltrating $\mathrm{T}$ cells and impact of lymphocytic infiltration on cytokine mRNA profile in prostatic tissue. Lab Invest 2003;83:1131- 46.

11. Kramer G, Steiner GE, Handisurya A, Stix U, Haitel A, Knerer B, Gessl A, Lee C, Marberger M. Increased expression of lymphocyte-derived cytokines in benign hyperplastic prostate tissue, identification of the producing cellt ypes, and effect of differentially expressed cytokines on stromal cell proliferation. Prostate 2002;52:43-58.

12. Steiner GE, Newman ME, Paikl D, Stix U, Memaran-Dagda N, Lee C, Marberger MJ. Expression and function of pro-inflammatory interleukin IL-17 and IL-17 receptor in normal, benign hyperplastic, and malignant prostate. Prostate 2003;56:171-82.

13. Jin X, Lin T, Yang G, Cai H, Tang B, Liao X et al. Use of Tregs as a cell-based therapy via CD39 for benign prostate hyperplasia with inflammation. J Cell Mol Med. 2020 May;24(9):5082-96.

14. Bai J, Wang S, Liu J, Ye Z, Yu X, Xi Q et al. Characterization of circulating CD4+ CD25 high regulatory T cells in men with chronic prostatitis/chronic pelvic pain syndrome. Urology 2010; 75: 938-42.

15. Daniels N, Ewing S, Zmuda J, Wilt T, Bauer D. Correlates and prevalence of prostatitis in a large community-based cohort of older men. Urology 2006;66(5):964-70.

16. Theyer G, Kramer G, Assmann I, Sherwood E, Preinfalk W, Marberger $\mathrm{M}$ et al.. Phenotypic characterization of infiltrating leukocytes in benign prostatic hyperplasia. Lab Invest 1992;66:96-107.

17. Harrington LE, Mangan PR, Weaver CT. Expanding the effector CD4 T-cell repertoire: the Th17 lineage. Curr Opin Immunol 2006;18:349-56.

18. Wan YY, Flavell RD. How diverse- CD4 effector T cells and their functions. J Mol Cell Biol 2009;1:20-36.

19. Nakae S, Nambu A, Sudo K, Iwakura Y. Suppression of immune induction of collagen-induced arthritis in IL-17- deficient mice. J Immunol 2003;171:6173-7.

20. Kramer G, Marberger M. Could inflammation be a key component in the progression of benign prostatic hyperplasia? Curr Opin Urol 2006; 16:25-9.

21. Wang L, Yang JR, Yang LY, Liu ZT. Chronic inflammation in benign prostatic hyperplasia: implications for therapy. Med Hypotheses 2008; 70:1021-3.

22. Penna G, Fibbi B, Amuchastegui S, Cossetti C, Aquilano F, Laverny $\mathrm{G}$ et al. Human benign prostatic hyperplasia stromal cells as inducers and targets of chronic immuno-mediated inflammation. J Immunol 2009; 182:4056-64.

23. De Nunzio C, Kramer G, Marberger M, Montironi R, Nelson $\mathrm{W}$, Schröder $\mathrm{Fb}$ et al. The controversial relationship between benign prostatic hyperplasia and prostate cancer: the role of inflammation. Eur Urol 2011; 60:106-17.

24. Ablin RJ, Gonder MJ, SoanesWA. Localization of immunoglobulins in human prostatic tissue. J Immunol 1971 Aug;107(2):603-4.

25. Ponniah S, Arah I, Alexander RB. PSA is a candidate self antigen in autoimmune chronic prostatitis/chronic pelvic pain syndrome. Prostate 2000;44:49-54.

26. Davidsson S, Andren O, Ohlson AL, Carlsson J, Andersson SO, Giunchi $\mathrm{F}$ et al. FOXP3+ regulatory $\mathrm{T}$ cells in normal prostate tissue, postatrophic hyperplasia, prostatic intra epithelial neoplasia, and tumor histologic allesions in men with and with out prostate cancer. Prostate. 2018;78(1):40-7.

27. López-Hoyos M, Segundo DS, Fernández-Fresnedo G, Marin MJ, González-Martin V, Arias M. Regulatory T cells in renal transplantation and modulation by immunosuppression. Transplantation 2009; 88: 31-9.

28. Gupta S, Shang W, Sun Z. Mechanisms regulating the development and function of natural regulatory T cells. Arch Immunol Ther Exp. 2008;56:85-102. 